Öneri. C.1. S.6.

Ocak, 1997, ss.9-11

\title{
ETKİLİ TAKIM ÇALIŞMASI KURALLARI
}

\author{
Dr.Canan ÇETİN
}

MÜ İIBF İşleme Bölümü, Doçent

ABSTRACT: In our study, the importance of the notion of team, the difference between team and group, and the characteristics of the effective teamwork have been mentioned.

\section{I-GIiRIŞ}

Toplam kalite yönetiminde, sorun çözme gruplarında (QCC) ve yeniden yapılanmada takım ile çalışmasının ne kadar önemli olduğu ve öneminin yaygınlaştığı görülmektedir. Hatta takım çalışması bunların başarı ile uygulanabilmesindeki en önemli bir özelliği oluşturmaktadır.

Takım çalışması, örgüt içinde çalışanlar arasında iletişimi (etkileşimi), bağımsızlığı geliştirip güven ortamının oluşmasına zemin hazırlar, çalıșanların ihtivaçlarını giderir motivasyonu arttırır.

Takım kavramına benzer bir kavram da grup kavramı olarak karşımıza çıkmaktadır. Bu kavramlar çoğu kez de birbirlerinin yerine kullanılmakta ve aralarında bir ayrım yapılmamaktadır. Takım çalışmasıyla. rekabetin ortadan kalkacağı. gerçek hayatların yaşanabilir hale getirilip kişilerin birbirlerine yardım edecekleri ortamlar yaratılabileceği ifade edilmektedir Takım: aynı hedefle bileşmiş, birbirleriyle bağımlı. dürüst. geçekçi ve açık insanların biraraya gelerck sinerji oluşturdukları bir yapıdır[1]. Grup ise: özel amaçları geliștirme hususunda başarısız ve etkisi olabilmektedir Dolayısıyla takım ile faklılığı otaya çıkmaktadır. Sineji ise: bütününün. paçalarla bütünleşir[2].

Gruplann başlıca özellikleri şi şcklilude ifade edilmektedir:

1.Grubun hedefi yeteri kadar planlanmadığı için grup üyeleri kendilerinde yoğunlaşır ve kendilerini 8 işin bir paçası, önemli bir paçası olarak hissetmez ve sanki o işin yapılması için kiralanmıs olduklarımı düşünüp buna uygun davranabilirler

- 2.Grup üyeleri kendilerinin işletmede var olma nedeni olarak: işletmenin genel amaçların karşılamak için getirildiklerini düşünürler ve bu yüzden de zaman zaman birbirlerine karşı çalışabilir.
3.Grup üyeleri. diğer üyelerin rollerini bilmediklerinden dolayı onlara güvenmeyebilirler. Hatta herhangi bir düşünceye karşı olmalı: bölücülük ya da destekçi olmayan bir tasarı olarak algılanabilir.

4.Üyelerin bir işin nasıl en iyi şekilde yapılacağ hususunda fikirlerinden yararlanma yerine onlara ne yapacakları söylenir.

5. Üyelere ne yapacakları söylendiğinden dolayı; bunlar iyi bir eğitim almıs olsalar da bu bilgilerini. yeteneklerini işe dönüştürmeleri sınırlandırılmıştı.

6. Üyeler diğer üyelerle iletişimlerinde çok tedbirli davrandıklarından dolayı; herhangi bir olgu ya da olay ile ilgili mesaj. görüș. düşünce, davranıș vb. Ne derece gerçeği yansıttığını anlamalı mümkün olamayabilir.

7.Grubun yöneticisi. ancak grubun çözemediği bir sorun halinde müdahale edebilir.

8.Üyeler grubu etkileyen kararlara katılabilirlerse de herşeyden önemlisi üyelerin normlara uygun davranmasıdır. sonuç değildir.

Takımın başlıca özellikleri de şu şekilde ifade edilmektedir:

1.Takımın üyeleri, işlerini sahiplenme duygusuna sahiptirler ve hedefin gerçekleșebilmesinde kendilerini tek sorumlu gibi hissedebilirler

2.Takım üyelerinin her biri birbirleri için önemli ve bağımlı olduklarını bilirler ve bunun farkındadırlar. Hedefe ancak karşılıklı destekle ulaşabileceklerini bilirler.

3.Takım üyeleri bilgi ve yeteneklerini işe dönüştürüp işe kullanarak örgütün amaçlarına katkıda bulunabilirler. Çünkü onlardan bir ișin nasıl en iyi şekilde yapılacağı hususunda fikirlerinden yararlanılır. Böylece iç girişimcilik (entrapraneurship) teşvik edilir. Üyeler de yaratıcılıklarını kullanma firsatı bulabilirler. $\mathrm{Bu}$ da onların motivasyonunu arttırıp. işletmenin başarısına katkıda bulunabilir.

4. Takım üyeleri diğer üyelerin rollerini bildiklerinden dolayı onlara güvenir, güven ortaminda çalışırlar. duygu. düşünce ve fikirlerini karşı oldukları 
konularda söyleyebilmeleri için sürekli cesaretlendirilirler.

5.Üyeler diğer üyelerle iletişimlerinde etkileşime girerler. Önce kendilerini farkedip anlamaya sonra da diğer üyeleri farkedip anlayamaya çalışırlar. Açı bir iletişim sergilerler. Kendileri tarafindan bilinen ve başkaları tarafından bilinen alanlarını genişletmeye çalışırlar. Bunun yanısıra olgu ya da olaylara diğer üyelerin bakış açısı ile bakabilmeyi, onları olduğu gibi kabullenmeyi, onları anlamaya çalıșırlar.

6.Fikirler arasında oluşabilecek çelişki; üyeler arasında hem yaratıcılık hem de yeni düşüncele için birer firsat olarak değerlendirilir. Üyeler; çelişkiyi yapıcı olarak hızlı bir şekilde çözmek için uğraşırlar.

7.Üyeler; takımlarını etkileyen kararlara katılırlarsa da takımın karar veremediği istisnai durumlarda takım liderinin son kararı vereceğini bilirler. Önemli olan sonuçtur

Bilindiği gibi takım çalışması bütün ortamlarda var olabilecek önemli bir çalışma şeklidir. Takım çalışmasında yukarıda da değinildiği gibi yüksek motivasyon vardır. Takım üyeleri: kendine gerçekleştirme, aidiyet ihtiyaçlarını. başarma ihtiyacını. vb. Takım içinde giderebilmektedir. Böylece lider. üyelerin iş ve gelecek yaşantıları ile ilgili beklentilerini de katkıda bulunabilirse. sonuçta onları ödüllendirerek doyumlarını sağlayabilirse bu da motivasyon açısından işteki verimin arttırılması hususunda çok önemlidir.

Takımda kararlara katılım da yüksek olup. görevin yerine getirilmesinde. için yapılır esasına uygun olmasında vizyonun paylaşımını gerçekleştirebilmek de uzunca bir süreyi alır.

Eğer takımla ilgili herhangi bir sorun takım içinde çözülmezse ve takımdaki herkesin gücü enerjiye dönüştürülmezse yukarıda da değinildiği gibi sinerjik bir etkiden söz edemeyiz. O yüzden mutlak surette bu tür sorunların takım içinde çözümü ve gücün ve enerjiye çevrilmesi gerekir. Başarılı bir takım çalışması ortaya koyabilmek için dikkat edilmesi gereken kurallar vardır. Herşeyden önce:

\section{-Takımın oluşturulma nedeni,}

-Takımın yerine getireceği işler (fonksiyon) un ne olduğunur tüm üyelerce bilinmesi.

-Takımın: üyelerin ihtiyaçlarını giderip onlara cevap verebilecek şekilde düzenlenmesi.

-Somut ledeflere yöneltilmesi, amaca uygun olarak çalışmayı kolaylaştıracaktır.

Bir takıraın etkili bir çalışma yürütülebilmesi için aşağıda belirtilen hususlara sahip olması gerekmektedir. Bunları şu şekilde açıklayabiliriz:[3]
1.Somut amaçlar: Takım amacının planlanmış ve somut, takımın görevinin açık olarak belirlenmesi ve herkes tarafindan kabul edilmesi gerekir ki bunlar takımdaki üyeler tarafından da paylașllıp, benimsenebilin.

2.Açı iletişim: bilindiği gibi iletişim; açı ve avunucu iletişim diye ikiye ayrılmaktadır. Avunucu iletişim daha çok kişinin kendini hep haklı çıkarmaya, karşı tarafı yargılamaya, Suçu bir başkalarında aramaya çalışan bir iletişim türü. Açık iletişim ise; herhangi bir olay ya da olgu oluştuğunda yer ve zaman unsurlarını da dikkate alarak, Q olay ya da olgu ile ilgili gerçek duygu ve düşünceyi ilgili kişiyle içten, samimi olarak paylaşmayı gerektirir. Takım çalışmalarında da önemli olan iletişimin açık iletişim yanıdır. Çünkü burada etkileşim ve dolayısıyla sinerji öz konusudur. Takım üyeleri yerine getirecekleri iş ve görevleriyle ilgili hislerini açıklamada özgürdürler. Hatta bu iletişim iş yaşantıları dışında da devam edebilir.

3.Risk alma: Takım üyelerinin yaratıcılıkları teşvik edildiğinde iç girişimciliklerinden yararlanılabilir. Böylece üyeler risk almaya istekli hale gelirler. Takım çalışmasında da bu özendirilmelidir[4].

4.Biçimsel olmayan iletişim: Üyeler arasında biçimsel iletişimin yanısıra biçimsel olmayan bir iletişimin mevcudiyeti: üyeler arasında rahatlığı ve huzuru sağlayabilir.

5.Dinleme: Takım üyeleri birbirlerini doğru olarak anlamaları için dinlemeleri gerektiğini bilmelidirler. Ancak birbirlerini dinleyerek. anlayarak bilgiler birleştirilir ve üzerinde bir yorum yapılabilir.

6.'Takım ile ilgili kararlara katılım: Kararlara katılım hususunda takım üyeleri tartışmalara katılabilir ve fikirlerini de rahatça paylaşabilirler. Tüm üyeler katılım için cesaretlendirilmeli. Kararla ilgili herkes fikri alınır. tartışılır ve sonunda bir karara varılır[5].

7.Paylaşılan liderlik: Her takım bir lidere sahip olsa da bir liderin işleri takım üyeleri tarafından takımın yetenek ve ihtiyacına göre zaman zaman değişebilir[3].

8. Sürekli gelişme ve kaliteyi geliştirme: Takım üyeleri bu çalışmalarla çalışma hayatının kalitesini de etkileyebileceklerdir. Bu çalışmalar antik olmamalı. tıpkı eğitim de olduğu gibi sürekli olmalı. Tüm bunlarla birlikte kalite de ihmal edilmemeli.

9. Çevre ile ilişkiler: Takımlar süreklilikleri için çevre ile de iletişimlerini devam ettirmelidirler. Cevre ile iletişimi: ayrıca bir diğer husus olan kaynak bulmada da çok önemlidir

10 Kaynak ihtiyacı: Takım etkin ve verimli olarak çalışabilmek için her zaman kaynak ihtiyacı içindedirler[6]. 
Öneri, C.1, S.6.

\section{II-SONUÇ}

Sonuç olarak: takımları etkin kılan onu oluşturan üyelerdir. Takımlar hiçbir zaman hazır olarak bulunamazlar. Ancak takım üyeleri; sürekli gelişmeye, sürekli kalitenin iyileștirilmesine, sürekli mükemmel çalışma ortamının oluşturulmasına katkıda bulundukları ölçüde takım vardır.

İster grup, ister takım olsun. üyeler; önce kendilerinin sonra da diğer üyelerin farkına varmalı önemsemeli benimsemeli. olay ya da olgulara bakış açısını genişletmeli, çalışırken de işbaşında yeteneklerini kullanma, kendisiyle ilgili kararlara katılma. işinin önemli parçası olma, vb. İhtiyaçlarını karşılayabilmeli. Takım içinde sorunun çözümü tüm üyelerce yararlı olmalı. Amaç kendinizin ve karşıdakinin gelişmesidir. Sorunun çözümü için, sorunun bir parçası olan herkesin çözïm önermesine izin verilmelidir ve onları tanımalı

\section{YARARLANILAN KAYNAKLAR}

[1]-KATZENBACH, John R.; SMITH, DOUGLAS K.; The Wisdom of Teams: Creating the HighPerformance Organization, Harper Business, 1993, s.22,1.30.

[2]-CÜCENOĞLU, Doğan: İçimizdeki Biz: Kalite Bilincinin Temeli, Sistem Yayıncilk A.Ş., İstanbul, 1996, s. 244

[3]-LEIGH, David; Total Quality Management (TQM): Training Module on "Empoverment Teamwork", Teple Junior College, 1993 s.56,57

[4]-CHARLENE, B. Adair; The Human Side of Just-in-Time, American Management Association, s.36 1991

[5]-COWING, Margaret; Positive School Discipline; A Practical Quide To Developing Policy, Longman, 1990, s.40.

[6]-SUNDSTROM, E., "Work Teams: Applications and Effectiveness" American Psychologist. s.45, 1990. 